\title{
Libya: 35 år med Gadafi
}

I september 2004 var det 35 år siden Mu' ammar al-Gadafi grep makten i Libya. Hans regime feiret seg selv, men den store folkefesten uteble. I hvilken grad er libyerne tilfreds med sin hersker?

Av Stig Stenslie, statsviter med spesialisering innen Midtøsten og Nord-Afrika.

DENNE ARTIKKELEN RETTER søkelyset mot sammenhengen mellom regimelegitimitet og -stabilitet i Libya. Målet er å undersøke hvorvidt Mu' ammar al-Gadafi har lykkes med å bygge legitimitet for sitt styre. Michael C. Hudson hevdet så tidlig som i I977 at det største problemet de arabiske regimene står ovenfor er mangelen på legitimitet, det vil si frivillig tilslutning til regimene fra folket.

Til tross for dette har den arabiske verden de siste tiårene ikke vært politisk ustabil. Tvert imot. Regionen har siden Hudson skrev sin bok på I970-tallet vært meget stabil. Gadafis Libya er intet unntak. Han har nå styrt landet i 35 år. Hudson mente at Gadafi, til forskjell fra andre arabiske statsledere, hadde lykkes i å bygge en viss legitimitet for sitt styre. Hvordan har han forsøkt å bygge legitimitet? Har han virkelig lykkes?

\section{Fem strategier for å bygge legitimitet}

Hvorfor er det viktig for en hersker å bygge legitimitet for sitt styre? I følge Max Weber er legitimitet en forutsetning for et godt styre som er stabilt over tid. Et regime kan overleve en stund på frykt eller vane, men det vil være usunt - preget av undertrykking og mangel på frihet - og før eller siden oppleve ustabilitet. ${ }^{2}$ Senere forskere som David Easton, David Apter og Tedd Gurr deler dette synet. ${ }^{3}$ Erfaringen med arabiske stater viser at regimer godt kan overleve uten legitimitet. Men regimene er langt fra sunne, og det er grunn til å sette spørsmålstegn ved hvor lenge de vil vare.

Hvordan kan en hersker så bygge legitimitet? Ulike strategier for å bygge legitimitet er analysert av forskerne nevnt ovenfor og mange andre. Hudson analyserer de strategier som arabiske herskere benytter. ${ }^{4}$ Samtidig som Hudson skrev sin studie begynte oljeboomen i flere arabiske land, særlig i Gulfmonarkiene. Tallrike nyere studier søker å vise hvordan herskerne i disse statene benytter inntekter fra salg av olje og gass, såkalte renteinntekter, for å bygge legitimitet for sitt styre. Noen eksempler er analysene til Hazem Beblawi, Giacomo Luciani og Gregory F. Gause. ${ }^{5}$

I den arabiske verden har den fremste sjeiken (ærestittel benyttet blant annet med referanse til politiske ledere), eller 


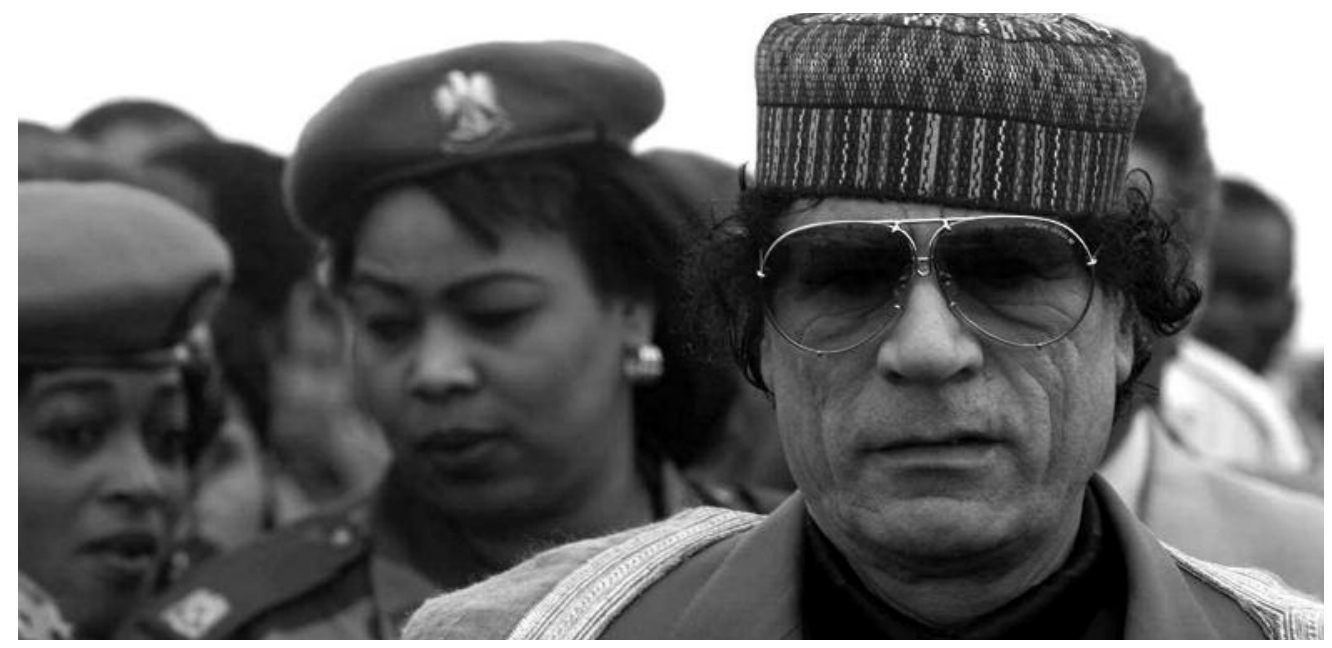

Gadafi på statsbesøk i Zambia i I999. REUTERS

FOTO: JUDA NGWENYA,

herskeren, tradisjonelt sett søkt å bygge legitimitet for sitt styre ved å innfri ett eller flere av fem følgende krav: ${ }^{6}$

- personlig karisma

- tradisjon, videreføre verdier nedfelt i statsstyre og samfunn

- beskytte, opprettholde, eller helst bedre, undersåttenes levestandard

- atferd og styresett i henhold til islam

- effektivt håndtere internasjonale relasjoner

Dersom en hersker er ute av stand til å innfri ett av disse kravene kan han normalt sett kompensere ved å leve opp til de andre. Men dersom herskeren har problemer med å imøtekomme flere av disse kravene, vil han ha vansker med å bygge legitimitet for sitt styre.

\section{Gadafis strategier for å bygge legitimitet}

Hvilke strategier har Gadafi benyttet for å bygge legitimitet for sitt regime? I I969 tok den 27-årige løytnant Gadafi - sammen med rundt 70 andre "frie offiserer" makten i Libya giennom et ublodig kupp. Gadafi avviklet monarkiet og proklamerte republikken Libya for opprettet. Slagor- dene for den nye republikken var folkestyre, sosialisme, islam, arabisk enhet og kamp mot Israel.' Siden Gadafi tok makten gjennom et kupp, og ikke gjennom etablerte mekanismer for lederskifte, var det viktig for ham å sette sine krefter inn på å bygge legitimitet for sitt styre. Han forsøkte alle fem nevnte strategier:

Personlig karisma: Gadafi er utvilsomt en karismatisk leder. Hans fargerike personlighet, lederevner og energi gjorde ham snart til Libyas sterke mann. ${ }^{8}$

En kilde til hans karisma er at han i utgangspunktet var en mann av folket. Gadafi ble født inn i den fattige berberstammen al-Gadafa. Han fikk tradisjonell utdanning. Eneste mulighet for sosial mobilitet for unge menn med hans bakgrunn var hæren. Gadafi var ferdig utdannet offiser i ig65. Etter dette gjennomgikk han opplæring på Royal Military Academy i Sandhurst, England. Gadafi spiller ofte på sin bakgrunn, og fremstiller seg selv som en fattig og enkel mann. Han ynder for eksempel å bo i et beduintelt når han er på statsbesøk i andre arabiske land, og har flere ganger brakt sine verter - sælig 
Saudi-Arabias kongefamilie - i forlegenhet ved å kritisere deres dekadente livsførsel.

En annen kilde til Gadafis karisma er at han knyttes til bruddet med kong Idris' upopulære styre, samt senere politiske og sosioøkonomiske reformer. Idris ble

Gadafi er en meget autoritoer hersker. All makt ligger $i$ hans hender. Han har ikke videreført tradisjonen med statsløshet i Libya.

innsatt som konge av britene da Libya ble uavhengig i I95I. Han ble valgt fordi han var leder for Sanusi-ordenen eller brorskapet. Med sine reformideer og i opposisjon mot tyrkiske, franske og senere italienske inntrengere kom dette brorskapet fra og med første halvdel av I80o-tallet til å utvikle seg som et politisk lederskap for folket i det senere Libya. ${ }^{9}$ Idris styrte Libya som et absolutt monarki, tilranet seg statens oljeinntekter og dyrket nære bånd til USA og Storbritannia. Samtidig ble den unge Gadafi gjennom sine egyptiske lærere og Radio Kairo eksponert for tankene til Egypts karismatiske leder, Gamal 'Abd al-Nasser, som senere skulle bli hans forbilde. Som Nasser talte Gadafi sosialisme, arabisk enhet og kamp mot Israel. Gadafi mobiliserte folket til politisk deltakelse, fordelte oljeinntektene og brot med Vesten. Omleggingen som fulgte i kjølvannet av revolusjonen ble knyttet til hans person.

En tredje kilde til Gadafis karisma er hans status som politisk tenker. Han skrev i årene etter revolusjonen Den grønne boka. I bokas tre bind beskrev han i detalj hvordan Libya skulle styres og hvordan de sosioøkonomiske forholdene burde være, den såkalte Tredje universelle teori. ${ }^{\text {. }}$

Tradisjon: Flere forskere har påpekt tradisjonen med det statsløse samfunn i Libya. En av disse, Lisa Anderson, sporer røttene til "statsløsheten" tilbake til I800og I900-tallet. Libya er et stort, men sparsommelig befolket land bestående av regioner med distinkte trekk (Tripolitania, Cyrenaica og Fezzan). Under både tyrkere, italienere og det senere kongedømmet til Idris forble den libyske staten lite utviklet. Utenfor byene Tripoli og Benghazi styrte lokale stamme- og landsbyhøvdinger. Hovdingene fattet beslutninger etter prinsippene om shura (rådslagning) og ijma' (konsensus), to politiske prinsipper nedfelt i arabisk-islamsk tradisjon. ${ }^{\text {II }}$

Gadafi har siden han tok makten hevdet at det ikke eksisterer noen stat i Libya og at folket er landets regjering. Selv omtaler han seg som "Bror, veileder for revolusjonen". Gadafis Tredje universelle teori anerkjenner tilsynelatende tradisjonen med fravær av statsmakt. Teorien ble etter revolusjonen provd ut i praksis. Libyerne ble beordret til å ta landets styre i egne hender gjennom deltakelse i folkekomiteer på lokalt og sentralt plan. Alle libyere skulle ta del i rådslagning og konsensusbygging. Libya skulle bli en jamahiriyyah (massestat, eller folkerepublikk). Komiteene overtok styret av blant annet byråkratiet, universitetene, private foretningsforetak og media. Til sammen ble rundt 2000 komiteer opprettet. I tillegg til folkekomiteene etablerte Gadafi revolusjonskomiteer som skulle overvåke arbeidet i folkekomiteene, samt bidra til at folket opprettholdt den revolusjonære gløden. Hæren ble foreslått 
erstattet av en folkehær bestående av borgere som ble gitt våpentrening, noe som imidlertid aldri ble realisert. I praksis ble Gadafis massestat et svært komplisert politisk system bestående av komiteer med til dels overlappende jurisdiksjon. ${ }^{\text {I2 }}$

Beskyttelse: Gadafi overtok et land hvor forskjellen mellom fattig og rik var meget stor. I I958 oppdaget Esso Oil sort gull under ørkensanden. Forut for dette var Libya verdens fattigste land. En av statens viktigste inntektskilder var salg av skrapjern fra andre verdenskrig. Bare én av ti libyere kunne lese og skrive, og færre enn ti personer hadde universitetsutdannelse. Libya kom til å dekke en tredjedel av VestEuropas petroleumsimport. Libysk olje var billig å produsere, hadde gunstig plassering i forhold til det europeiske petroleumsmarkedet og var ettertraktet på grunn av sitt lave svovelinnhold. Men kongen og hans slektninger tok alle oljeinntektene.

For å sikre inntekter til staten nasjonaliserte Gadafi oljeindustrien. Oljeboikotten i I973 mangedoblet statens inntekter. Gadafi lot alle libyere få en del av inntektene. Dette var dels ideologisk begrunnet, dels motivert ut fra et behov for å bygge støtte for revolusjonsstaten. Et vugge-tilgrav-velferdssystem som ga libyerne gratis utdannelse og helsetjenester ble etablert. Staten begynte dessuten å subsidiere mat, vann, elektrisitet og boliger. Borgerne fikk alle disse tjenestene uten å betale skatt på inntekt, formue eller eiendom, unntatt zakat (almisse) tilsvarende $2,5 \%$ av årlig inntekt, en religiøs plikt for alle muslimer.

Muslimsk atferd og styresett: Libyas konstitusjon av I969 understreker at islam er statsreligion. Gadafi søkte rett etter kuppet å få støtte fra ' ulama (religiøse lærde) for sitt styre. Skulle revolusjonen overleve måtte allianser bygges. Geistlige ble gitt sentrale posisjoner innenfor retts- og utdanningsvesenet og ble konsultert før viktige beslutninger ble fattet. Gadafi talte dessuten ofte i moskeene. Men i I973 følte han seg sikker på sin posisjon. Gadafi oppløste Sanusi-ordenen, en av kong Idris' støttespillere, og brøt med dens doktriner. Gadafi vektla isteden de ortodokse islamske doktrinene om rettferdig styre og sosial rettferdighet. Han fremstilte den Tredje universelle teori som et alternativ til forfeilede ideologier som kapitalisme og kommunisme. Alternativet var islam. Teorien var ifølge Gadafi islam praktisert i et moderne samfunn. Både direkte folkestyre og økonomisk omfordelig ble begrunnet ut fra islams forbud mot urettferdige herskere og økonomisk utbytting.

Internasjonale relasjoner: Gadafi, som betraktet seg selv som den nye Nasser, har aktivt søkt å fremstille seg selv som både arabisk og afrikansk leder. Han tok på I970-tallet en rekke initiativ for arabisk enhet. Senere gjorde han lignende fremstøt på det afrikanske kontinent. I I973 invaderte han Tchad.

Gadafi har imidlertid ikke kommet noen vei med sine enhetsbestrebelser. De har ofte strandet på hans kompromissløse holdning i de fleste spørsmål. Gadafi, som allid har vært en steil motstander av Israel, søkte også å bygge opp et arsenal av masseødeleggelsesvåpen for å veie opp trusselen fra landet. Videre støttet han en rekke radikale organisasjoner assosiert med internasjonal terrorisme, herunder PLO og IRA. Libya ble på I980-tallet knyttet til flere terroraksjoner, hvor de alvorligste var anslaget mot nattklubben La Belle i Berlin i I986, samt sprengningene av flyet Pan Am roz over den skotske byen Locker- 
bie i I988 - hvor 270 mennesker ble drept - og det franske flyet UTA 772 over Niger i 1989 .

Gadafis utenrikspolitikk førte Libya på kollisjonskurs med sentrale aktører i det internasjonale samfunn, sælig USA. Som en følge av Gadafis utenrikspolitikk iverksatte USA unilaterale sanksjoner mot Libya i 1986 og 1996. I tillegg beordret daværende president Ronald Reagan, Gadafis erkefiende, flyangrep mot de libyske byene Tripoli og Benghazi i juni I986. I angrepet ble 37 mennesker drept. En av de drepte var angivelig Gadafis 4årige adoptivdatter Hannah. FN innførte sanksjoner mot landet i 1992 (UNSCR 748) som ble utvidet i I993 (UNSCR 883). Gadafi fikk personlig en rolle som en rebell i det internasjonale samfunn som våget å stå opp mot Vesten. Denne rollen ga ham trolig en viss legitimitet.

\section{Strategiene svikter}

Har Gadafi lykkes i å bygge legitimitet for sitt styre? Fra begynnelsen av ig8o-tallet har tilsynelatende en etter en av hans strategier for å bygge legitimitet vist seg utilstrekkelige:

Personlig karisma: Weber mente at et regime vanskelig kunne arve en karismatisk leders legitimitet. ${ }^{14}$ Gadafi er i dag fortsatt ung, bare 6r år, men det spekulers $i$ at han er ved svak helse. Han skal ha både hals- og blodkreft. Hva skjer med regimets legitimitet den dagen han faller fra?

Det er en rekke indikasjoner på at Gadafi ønsker at ett av hans åtte barn skal etterfølge ham som Libyas leder. ${ }^{15}$ Fremst i køen står 33-årige Sayf al-Islam, vellykket foretningsmann (med hans familieforbindelser skulle det bare mangle) og farens høyre hånd. Sayf al-Islam var i sin tid kronprins Haakons studiekamerat ved London School of Economics. Han har selv avvist spekulasjonene om at han vil ta over etter faren, men fremstår mer og mer som Libyas kronprins. Han har ingen formell posisjon, men er mannen å gå til dersom en vil ha noe gjort. Videre i rekken kommer 34-årige Muhammed som leder Libyas olympiske komité, samme posisjon som Saddam Husseins sønn Uday hadde i Irak. Dernest kommer 3I-årige fotballgale Saadi. Han har vært president for Libyas fotballforbund, og signerte i juli 2003 for den italienske Serie A-klubben Perugia. Kokain har imidlertid stått i veien for hans debut.

En kleptoman elite bestående av Gadafis familie og noere allierte stjeler mesteparten av inntektene.

Gadafis 28-årige datter, Aisha, er nevnt som en mulig første kvinnelige president $i$ en arabisk stat. Hun har doktorgrad i jus fra Sorbonne-universitetet i Paris. Utseendet har gitt henne betegnelsen "Libyas Claudia Schiffer" i kulørte italienske ukeblader. Aisha har arvet farens uhemmede radikalisme. I 200I erklærte hun sin støtte til IRA fra Speaker' s Corner i London, og sommeren 2004 forsøkte hun å bli oppnevnt som en av Saddam Husseins forsvarere. Imidlertid er det lite sannsynlig at Aisha vil bli akseptert som president $i$ det konservative og stammedominerte Libya hvor kvinner har like få rettigheter som i Saudi-Arabia.

To forhold taler for at Sayf al-Islam faktisk blir Libyas neste hersker: For det første vil dette sikre en videreføring av 
posisjonene og privilegiene til de som i dag er i kretsen rundt Gadafi, og for det andre er familiebakgrunn viktig i libysk politikk. Hvordan vil et far-til-sønn lederskifte påvirke regimets legitimitet? Tross degenereringen av Libya til en "dynastisk republikk”, vil Sayf al-Islam sannsynligvis ha en viss legitimitet som sin fars sønn. Han blir dessuten som faren beskrevet som en karismatisk mann; eksentrisk, provoserende og uforutsigbar. ${ }^{16}$

Tradisjon: Gadafi har tilsynelatende søkt å bygge legitimitet for sitt styre ved å videreføre tradisjonen om statsløshet. Hvor plausible er hans påstander om at det ikke eksisterer en stat i Libya og at folket styrer landet?

Gadafi er en meget autoritær hersker. All makt ligger i hans hender. Gadafi har med andre ord ikke videreført tradisjonen om statsløshet i Libya. Bakenfor komitékaoset har han bygget opp en sentralstyrt skyggestat. Innerste sirkel i skyggestaten består av Gadafi og hans mest betrodde; Gadafis familie og enkelte veteraner fra kuppet $i$ I969. Denne eliten besitter alle nøkkelstillinger i statsapparatet og treffer de viktigste politiske beslutninger. Neste sirkel består av al-Gadafa-stammen, samt allierte stammer som Magharha og Warfalla. Menn fra disse stammene rekrutteres til spesialstyrkene og etterretningstjenesten, de mest betrodde elementer av Gadafis maktapparat. I den ytterste sirkelen er den ordinære hæren og politistyrkene, som er mindre betrodde elementer av maktapparatet, samt det eneste tillatte partiet, Den arabiske sosialistiske union, som fungerer som et stort, landsdekkende angivernettverk.

Det libyske folket styrer ikke landet. Medlemmer av middelklassen som ble rammet av nasjonaliseringen på I970-tal- let, samt studenter og intellektuelle, har etablert eksilgrupper i Vesten som krever demokrati. Globaliseringen har også brakt ideen om demokrati til Libya. Men innad i landet er det få som tør kreve rett til politisk medbestemmelse. Det er lite sannsynlig at Gadafi i nærmeste fremtid vil iverksette dyptgripende politiske reformer som kan eksponere hans regime for større kritikk og undergrave hans maktbase. Libyas leder vil for eksempel ikke granske ledende regimepersoner for brudd på menneskerettighetene, som er et omfattende problem. ${ }^{17}$

Beskyttelse: På grunn av sensur og undertrykkelse av all opposisjon er det vanskelig å skaffe til veie troverdig informasjon om den sosiale og økonomiske situasjonen i Libya. Heller ikke offentlige statistikker er tilgjengelige. Blant alle land i Afrika har Libya høyest inntekt per innbygger, og landet har ikke utenlandsgjeld. Libya har en befolkning på 5,6 millioner mennesker (medregnet I,5 millioner fremmedarbeidere) og brutto innenlandsk nasjonalprodukt (BNP) på 23 milliarder US\$. Til sammenligning har Uganda 20,3 millioner innbyggere og BNP på bare 5,8 milliarder US\$, mens Kenya med sine 27,8 millioner innbyggere har BNP på 8,7 milliarder.

Til tross for disse tallene fikk Libya på slutten av I990-tallet store økonomiske problemer. Landets inntekter var fallende, samtidig som utgiftene økte. Hovedgrunnen til inntektsfallet var rekordlave oljepriser, helt nede i io US\$ per fat i 1998. For det andre var oljeproduksjonen synkende; fra 3,5 mill. fat/dag på I970-tallet til I,4 mill. fat/dag i I999. Produksjonsfallet var forårsaket av sanksjonene som hindret tilgang på kapital, USA-produserte reservedeler til oljeindustrien og eksper- 
tise. Økte utgifter var en konsekvens av at befolkningen hadde vokst hurtig; fra i underkant av to millioner mennesker i I973 til 5,6 millioner i I999. Halvparten av Libyas befolkning er i dag under I5 år. Den unge befolkningen utgjør et sterkt press på skoler og helseinstitusjoner. Innen få år vil presset rettes mot boliger og ikke minst arbeidsplasser.

På slutten av I990-tallet begynte de sosiale problemene å melde seg. Libyerne tjener mindre, tallet på arbeidsledige stiger (200.000 libyere er helt uten arbeid samtidig som det er én million gjestearbeidere i landet), kriminaliteten vokser og narkotikamisbruk blant unge er et økende problem. En lærers årslønn er knappe ı200 US\$, og tilbudet av helsetjenester er så dårlig at de som har råd til det drar til nabolandet Tunisia for å få medisinsk behandling.

Samtidig er Libyas inntekter meget skjevt fordelt. Gadafi hevder at Libya er "sosialistisk", men en kleptoman elite bestående av Gadafis familie og nære allierte stjeler i realiteten mesteparten av inntektene. Følgelig har Libyas oljerikdom i liten grad kommet vanlige libyere til gode. ${ }^{18}$

Muslimsk atferd og styresett: Gadafi har også vektlagt de islamske doktrinene om rettferdig styre og sosial rettferdighet for å legitimere sitt regime. I hvilken grad har han lykkes i å leve opp til disse muslimske idealene? Libyerne har begynt å uttrykke misnøye med å være fattige $i$ et rikt land. Gadafis tre tiår med politiske eventyr og vanstyre får skylden. Særlig er motstanden mot regimet sterkt i østprovinsen Cyrenaika. Stammene i dette området er isolert i forhold til hovedstaden Tripoli og har sett lite til oljerikdommen. Til tross for at Libya ifølge Gadafi er en stat styrt av folket, har libyerne ingen kanaler hvor de legitimt kan uttrykke sin misnøye. Islamister har organisert seg med det formål å velte Gadafis regime. ${ }^{19}$ Disse sto bak et mislykket kuppforsøk i ı984. På slutten av ı990-tallet startet flere mindre islamistgrupper en væpnet kampanje mot Gadafi-regimet i det østlige Libya. Medlemmene besto blant annet av "libyske afghanere", veteraner fra kampene mot russerne i Afghanistan på I980-tallet. Rundt 300 libyere deltok i kampene. ${ }^{2 \circ}$ Islamistenes strategi for å undergrave Gadafi-regimet var kidnappinger og attentatforsøk. Islamistene gjennomførte blant annet to mislykkede forsøk på å ta Gadafis liv, henholdsvis i I996 og I998. Det er indikasjoner på at det islamistiske opprøret nå er i ferd med å spre seg til vestprovinsen Tripolitania, hvor regimet tradisjonelt har hatt sterkest støtte i befolkningen. Pamfletter med kritikk av regimet distribueres i hovedstaden Tripoli og andre større byer i provinsen.

Men den største trusselen mot Gadafi har helt siden han tok makten kommet fra hæren. Misfornøyde soldater forsøkte å drepe Gadafi i I984 og I985.22 Soldatenes stammebakgrunn er avgjørende for hvilke avdelinger de havner i. Menn fra Gadafis egen stamme rekrutteres til lojale eliteavdelinger. Disse har godt utstyr og lønn. De ordinære styrkene, i kontrast til eliteavdelingene, består hovedsakelig av menn fra stammene i Cyrenaika. Disse er dårlig utstyrt og har i lange perioder ikke fått betaling. Mens soldatene i eliteavdelingene tjenestegjør nær hovedstaden, må de ordnære soldatene tjenestegjøre i de ugjestmilde ørkenstrøkene i provinsen Fezzan sør i landet. Gadafi, som selv tok makten gjennom et militærkupp, har iverksatt en rekke tiltak for å avverge et nytt kupp. Han roter- 
er hyppig offiserer mellom militærdistrikter, og mellom kommando- og stabsstillinger. Offiserer han mistenker for å være illojale førtidspensjoneres. I tillegg benytter han kubanske og tidligere østtyske offiserer.

Internasjonale relasjoner: I dag fremstår ikke Gadafi som den rampen i det internasjonale statssystemet som han en gang gjorde. Tvert imot har han vist vilje og evne til å spille på lag med det internasjonale samfunn. På slutten av I990-tallet søkte Libya å distansere seg fra grupper og personer assosiert med internasjonal terrorisme. Landet utviste ekstreme organisasjoner og personer, deriblant Abu Nidal i I998. Samme år aksepterte Libya å utlevere de to påstått ansvarlige bak Lockerbieaksjonen til FN, og bifalt at disse kunne stilles for en domsstol i Nederland.

Det siste året har tilnærmingen til Vesten skutt fart. I august 2003 aksepterte Libya å betale 2,7 mrd. US\$ i erstatning til de etterlatte etter sprengningen av Pan Am I03 over Lockerbie i I988. I desember 2003 erklærte Gadafi at Libyas program for utvikling av masseødeleggelsesvåpen umiddelbart skulle avvikles. Eksperter fra Storbritannia og USA, samt IAEA, fikk lov til å overvåke avviklingen. I januar 2004 møtte en israelsk opposisjonspolitiker Gadafis sønn, Sayf al-Islam, angivelig med det formål å forhandle frem en fredsslutning mellom Israel og Libya. I januar 2004 innvilget Libya I70 mill. US\$ i oppreisning til de etterlatte etter sprengningen av UTA 772 over Niger i I989. Og endelig i september 2004 godtok libyske myndigheter å betale 35 mill. US\$ i kompensasjon til de etterlatte etter angrepet mot nattklubben La Belle i Berlin i ı986. Gadafis velvilje kom overraskende på vestlige regjeringer som i to tiår hadde betraktet Libya som en "røverstat" og et semimedlem av "ondskapens akse" (i godt selskap med Cuba, Irak, Iran, Sudan, Syria og Nord-Korea). Som en følge av Gadafis snuoperasjon hevet FN sanksjonene mot Libya i september 2003

\section{I dag fremstår ikke Gadafi som den} rampen $i$ det internasjonale statssystemet som han en gang gjorde.

og USA gjenopprettet diplomatiske forbindelser med landet i juni 2004. USAs sanksjoner blir trolig snart opphevet. Vestlige selskaper, inkludert amerikanske, konkurrerer nå om lisenser for å få investere i Libyas oljeindustri.

Det var tre hovedårsaker bak Gadafis beslutning om å snu Libyas utenrikspolitikk på slutten av I990-tallet: For det første hadde Libyas økonomi blitt betydelig svekket av sanksjonene og rekordlave oljepriser. Regimet var ikke lenger i stand til å yte velferdstjenester til en stadig voksende befolkningen. Vestlige selskaper konkurrerer nå om lisenser for å få investere i oljeindustrien. Amerikanske oljeselskaper, som frykter å bli utkonkurrert av europeiske selskaper og vurderer mulighetene i Irak som usikre, har satt administrasjonen i Washington under press for å oppheve USAs sanksjoner. Trolig skaffet amerikanske selskaper til veie midlene som gikk til de etterlatte etter Lockerbie-angrepet. ${ }^{23}$

For det andre hadde islamistiske ekstremister fra tidlig på ı99o-tallet blitt stadig mer aktive i Libya. I tillegg forsterket misnøye innad i de væpnede styrkene 
sannsynligheten for et stammekupp. Gjennom å åpne opp for utenlandske investeringer håper nå libyske myndigheter å skape en generell velstandsøkning som vil fjerne det sosiale grunnlaget for islamsistisk ekstremisme, militækupp og stammereisning.

For det tredje ble Gadafi skremt av begivenhetene etter II. september 200 I invasjonene av Afghanistan og Irak. På grunn av Libyas masseødeleggelsesvåpenprogram trodde han at Libya var neste mål for USAs krigstokt. Gadafi ble klar over at han tjente på å spille på lag med USA i den såkalte "krigen mot terrorisme". Tilnærming til Vesten ble betraktet som nødvendig. Som så mange andre autoritære ledere drar nå Gadafi nytte av den USA-erklærte krigen mot terrorisme gjennom å slå ned på intern opposisjon. Hans trekk har båret frukter. Den libyske islamistorganisasjonen Libyas islamske kampgruppe, som han har gitt merkelappen al-Qaida, står nå på USAs liste over terrorbevegelser. USA og Libya har utvekslet etterretning om gruppen. Gadafi har uttalt følgende om arresterte islamister: "Disse vil bli behandlet som hunder, uten advokat eller menneskerettigheter ...Vi giør som USA." ${ }^{24}$

Det er vanskelig å vurdere hvordan vanlige libyere ser på Gadafis tilnærming til Vesten. På kort sikt kan libyerne oppfatte tilnærmingen som et knefall for USA og andre vestlige stater, men dersom trekket gir økonomisk vekst vil det på lengre sikt kunne bidra til økt oppslutning om hans regime.

\section{Konklusjon}

Gadafis Libya er ikke det unntaket Hudson en gang mente det var. Gadafi har som andre arabiske statsledere ikke lykkes i å bygge legitimitet for sitt styre. Som nevnt kan en hersker som er ute av stand til å innfri ett av kravene til legitimt styre normalt sett kompensere dette ved å leve opp til de andre. Men dersom herskeren har problemer med å imøtegå flere av disse kravene, vil han ha vansker med å bygge legitimitet. Det siste er tilfelle i Libya. Men vil Gadafis regime til tross for manglende legitimitet fortsette å eksistere i årene som

\section{Libyerne har begynt å uttrykke sin misnøye med å voere fattige $i$ et rikt land.}

kommer? To utviklingstrekk er sannsynlige: Libyernes misnøye med både den politiske og sosioøkonomiske tilstanden vil øke, og stadig større deler av folket vil kreve rett til politisk medbestemmelse. Historiske erfaringer fra både arabiske land og andre deler av verden viser at det første utviklingstrekket nesten alltid leder til det andre. Det neste spørsmålet er derfor; hvordan vil Gadafi imøtegå en slik utvikling?

Gadafi-regimet vil trolig fortsette å overleve flere år på frykt eller vane. Men det må også søke å bygge ny støtte for sitt styre. Libyerne har store sosioøkonomiske forventninger til fremtiden. På denne bakgrunn kan en forstå Gadafis tilnærming til Vesten. Hovedmotivet for snuoperasjonen er å styrke staten økonomisk slik at den igjen skal være $\mathrm{i}$ stand til å distribuere velferd til befolkningen. En generell velstandsøkning vil også kunne fjerne noe av det sosiale grunnlaget for den stadig mer radikale opposisjonen mot Gadafi.

Men vil fruktene høstet fra tilnærmingen 
til Vesten være tilstrekkelige for å bygge ny legitimitet? Det er verdt å merke seg at stadig flere libyere også har forventninger om rett til politisk medbestemmelse. Selv om Gadafi har et reelt ønske om økonomisk reform, står demokratisering ikke på hans dagsorden. Det er lite sannsynlig at Gadafi vil kunne klare å bygge ny legitimitet for sitt styre uten at også libyernes politiske forventninger imøtekommes.

$$
\text { - } f \cdot
$$

I Michael C. Hudson: «Arab Politics: the Search for Legitimacy». Yale University Press: New Haven and London, I977.

2 Max Weber: «The Theory of Social and Economic Organisation». Redigert av Talcott Parsons. Oxford University Press: New York, I947.

3 David Easton: «A Systems Analysis of Political Life». Wiley: New York, I965; David Apter: «Government». Institute of International Studies: New York, I968; Ted Gurr: «Why Men Rebel». Princeton University Press: Princeton, I970.

4 Hudson op. cit.

5 Hazem Beblawi \& Giacomo Luciani: «The Rentier State». Routledge: London. I987; F. Gregory Gause III: «Oil Monarchies». Council of Foreign Relations Press: New York, I994.

6 Gerd Nonneman: "Security and Inclusion", i Sean McKnight, Neil Partick \&Francis Toase (red.): «Gulf Security». Whitehall Paper Series: London, 2000.

7 Ruth First: «The Elusive Revolution». Penguin Books: London, I973; Nathan Alexander: ' Libya: the Continuous Revolution', Middle Eastern Studies, Vol. I7, Issue 2, I98I.

8 George Tremlett: Gadaffi: «The Desert Mysti»c. Pub Group West, I993; Janice Monti-Belkaoui \& Ahmed RiahiBelkaoui: «Qaddafi: The Man and His Policies». Avebury, I996.

9 E. E. Evans-Pritchard: «The Sanusi of Cyrenaica». Oxford University Press: London, I949; Nicola Ziadeh: «Sanusiyah: A Study of a Revivalist Movement in Islam». E. J. Brill: Leiden, 1968.

Io Mu' ammar al-Qaddafi: «The Green Book». The Green Book World Centre: Tripoli, I980.

II Lisa Anderson: «The State and Social Transformation in Tunisia and Libya, I830-I980». Princeton University Press, I986; Richard Pennell: 'Libya and Morocco', George Joffé (red.): «North Africa: Nation, State, and

Region». Routledge: London and New York, I993.

I2 Ronald Bruce St. John: 'The Ideology of Mu' ammar alQadhafi' , International Journal of Middle Eastern Stud-

Vol. I5, I983; Lillian Craig Harris: «Qadhafi’ s Revolution and the Modern State». Westview Press: Boulder, Colorado, I986; Dirk Vandewalle (red.): «Qadhafi's Libya I969-I994». St. Martins Press: New York, I995; Geoff Simons: «Libya: The Struggle for Survival». Palgrave MacMillian, I996.

I3 J. A. Allan: «Libya since Independence». Croom Helm: London, I982; George Joffe \& K. S. McLachlan: «Social and Economic Development of Libya». MENAS Press: Cambridgeshire, I982; Judith Gurney: «Libya: The Political Economy of Oil. Oxford University Press, I996.

I4 Weber op. cit.

I5 "Libya Country Report", The Economist Intelligence January 2004, S I5-I6.

I6 "Finding a Place for the Son", Financial Times, Septem$\mathrm{b}$ I2, 2004 .

I7 'Amnesty International Report', Amnesty International, 2003 http://www.amnesty.org; ' Freedom in the World', Freedom House, 2003 http://www.freedomhouse.org

I8 The Economist Intelligence Unit, op. cit

I9 Francois Burgat \& William Dowell: «The Islamic Movement in North Africa». University of Austin Press: Austin, Texas, I997; Emad Eddin Shahin: «Political Ascent». Westview Press: Boulder, Colorado, I998; Ray Takeh 'Qadhafi's Libya and the Prospect of Islamic Succes-

$\mathrm{S}$ Middle East Policy Council Journal, Vol. 7, Issue 2, 2000 http://www.meps.org/public_asp/journal_vol7/0002_ takeyh.asp

20 John K. Cooley: «Unholy Wars». Pluto: London, 1999

2I al-Hayat (London), I. februar I996 og I5. juni I998

22 Yehudit Ronen: 'Libya', i Itimat Rabinovitch \& Haim Shaked (red.): «Middle East Contemporary Survey I98485». Moshe Dayan Center for Middle Eastern and African Studies: Tel Aviv, I987, s. 56I-2

23 'And Now for the Oil' , The Middle East, August/September 2004; ' Libya' s Black Gold Rush', Fortune, Vol. I49, Issue 13, 2004; ' Reform Drive Pays Dividends' , Africa Monitor: North Africa, Vol. 9, Issue 9, 2004

24 Morgenbladet (Oslo), 7.-I3. mars 2003 